\title{
Examining Groundwater Pollution in Central Katsina City, Nigeria
}

\author{
Kankara, A. I. ${ }^{1}$ and Bazza, L. M. ${ }^{2}$ \\ 1. Department of Geography \& Regional Planning, Federal University Dutsin-Ma, Nigeria \\ 2. Department of Geology, Federal University of Technology, Minna, Nigeria
}

\begin{abstract}
The outlook for Nigeria's hygienic and or healthy water is not very promising. According to studies by the Federal Government, UN and the International Joint Commission Organization that studies common bodies between any two nations and many sections of the World, particularly Africa, are experiencing a shortage of fresh water and the problem will only persist. The third water forum of United Nations found that currently 450 million people in 29 countries lack safe drinking water. In Nigeria, problem bound on which tiers of government are responsible for safe guarding the fresh water resources. Unless something is done by the authorities concerned the future shall be bleak. The Nigerian National Policy on distribution of safe drinking water is an integral part of the National Policy on Environmental Protection and the Federal Ministry of Water Resources. Since the mid-20th century, Katsna State of Nigeria has witnessed an increase in ground water pollution due to human interferences and Population hike. Katsina State Government should pursue measures to ensure sustainable access to safe drinking water in the State. This paper focuses on issues arising from this ground water degradation and mismanagement in Urban Katsina, and the way forward.
\end{abstract}

Key words: Groundwater, pollution, Katsina State, Nigeria.

\section{Introduction}

In the year 2000, National Water Quality Inventory reported that agricultural nonpoint source pollution is the leading source of water quality impacts on surveyed streams [1], rivers and lakes, the second largest source of impairments to wetlands, and a major contributor to contamination of surveyed estuaries and ground water [2]. Agricultural activities that cause non-point source pollution include poorly located or managed animal feeding operations; overgrazing; flowing too often or at the wrong time; and improper, excessive, or poorly timed application of pesticides, irrigation water, and fertilizer. Lee and Jones [3], reported that the Californian Nitrate and DBCP (1,2-Dibromo-3-chloropropane) levels exceeding the State drinking water standards occur extensively in groundwater in the basins. Public and domestic supply wells have been closed because of DBCP, (ethylene

Corresponding author: Aliyu Ibrahim Kankara, Dr., research fields: mineral exploration, economic geology, geochemistry. dibromide) EDB, nitrates resulting from the agricultural practices and other contaminants in several locations $[4,5]$.

\section{Study Area}

Katsina metropolis (city) is situated between Latitudes $11^{\circ} 18^{\prime} \mathrm{N}$ and $13^{\circ} 22^{\prime} \mathrm{N}$, and Longitudes $6^{\circ} 52^{\prime}$ $\mathrm{E}$ and $9^{\circ} 20^{\prime} \mathrm{E}$. It was built on a spur of land between Ginzo and Tilla streams which flows in a north-easterly direction, and is at a narrow neck of water shed between the Gada and Tagwai River Basin (Fig. 1). Katsina is an ancient old City that was formerly a City State surrounded by City wall of 21 kilometers in diameter/length. Katsina is a local government Headquarter and the capital city of Katsina State. It is one of the 36 states that comprises the Federal Republic of Nigeria. The city is moderately populated with about 700,000 persons/settlers been recent estimated mainly as a result of natural increase and migration from other 


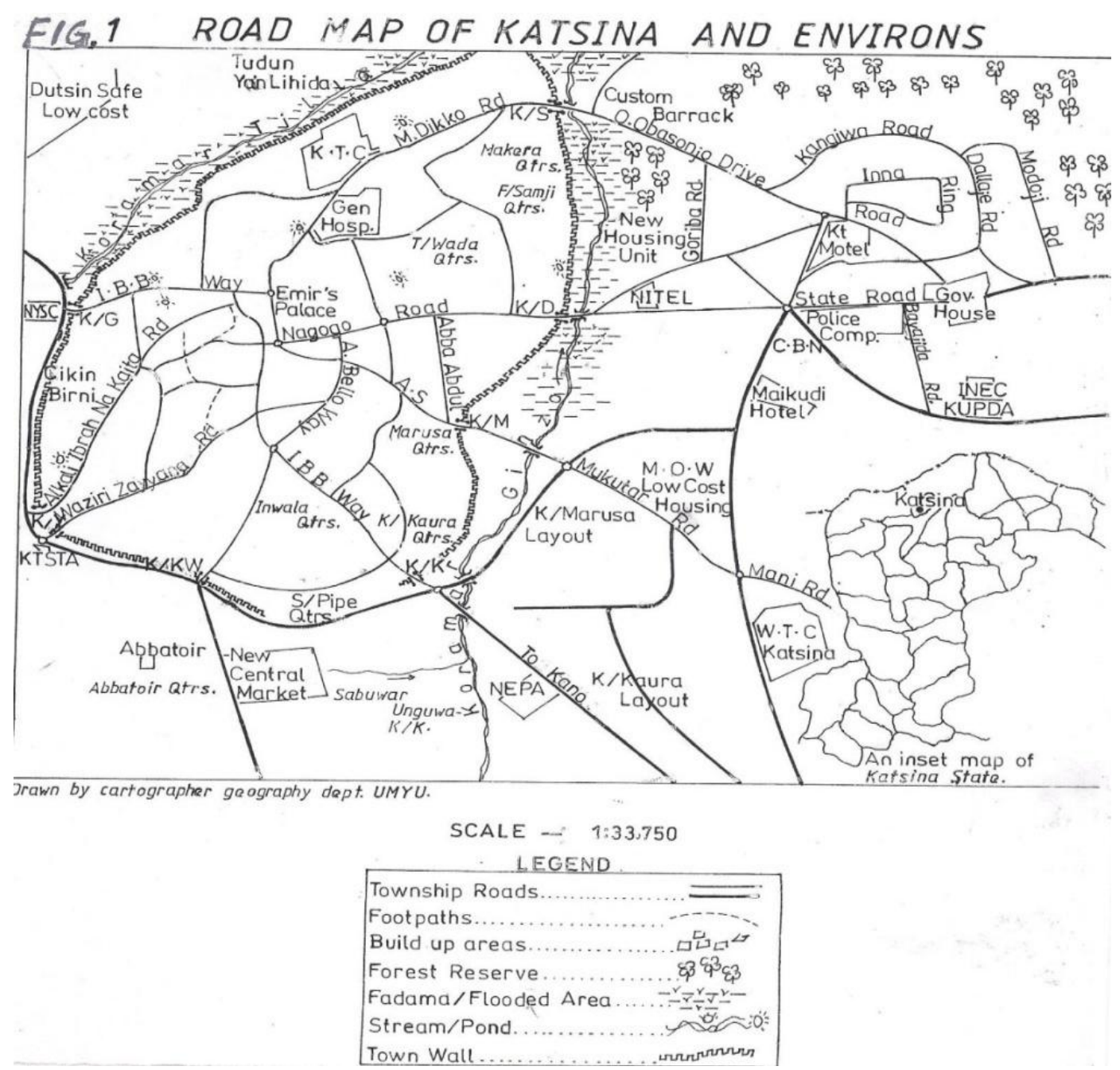

Fig. 1 Road map of Katsina and Environ.

cities that were affected by insecurity in northern Nigeria. The climate is Tropical Continental type, classified according to Kopen's Climate Classification as AW, with long dry season and short wet season [6].

Vegetation type is Sudan Savannah with short scattered trees and grasses. Most of the vegetation is affected by human activities such as deforestation for fuel wood and clearance of vegetation for residential purpose [6].

The geology of the area governs the nature of river flowage. The project area lies within the Nigerian Basement Complex which is divided into Crystalline basement of migmatites and gneisses. The crystalline basement initially behaved as one tectonic unit, but later experienced two periods of syntectonic metamorphisms with deformations in two successive phases called the Intense Alpine types deformations. The deformations took place during the Pan African orogeny which were accompanied by metamorphism, granitization and feldspatisation. The first tectonics resulted in extensive migmatisation of the basement but was further differentiated during the second tectonics to produce homogenous gneiss and intrusive granites [5].

The migmatites and gneiss represent the oldest rocks in the basement complex [7]. There are at least two generations of migmatitic gneiss of widely different ages within the study area. The migmatitic gneiss underlies mica schist, dipping south-east at between 270 and 430 with most outcrops observed in stream 
channels. The mica schists are generally fissile dark-grey to greenish grey in color and weather to a silvery to a light grey colored with red iron-oxide stains on its fissile surfaces [8].

\section{Methodology}

Geological mapping/water sampling of the project area was performed simultaneously in September 2014, which marked the peak of dry season. The mapping involved locating wells, streams and rivers with the use of GPS (Global Positioning System) and studying outcrop if any along all the traverse made while collecting water samples. The wells were chosen randomly, ensuring fair distribution over the entire project area and the choice of a well depended on its distance from a previously chosen one. In a locality, at least one well was sampled per grid. The samples were collected in duplicate from both surface and well waters which were stored in plastic containers because plastic gives least contamination that could alter the water chemistry [9].

The first container was a one-liter (1 litre) plastic container with which two drops of concentrated nitric acid $\left(\mathrm{HNO}_{3}\right)$ was added for cation determination. The essence of adding the acid is to homogenize and prevent adsorption of trace elements to the walls of the plastic containers. Acidification stops most bacterial growth, blocks oxidation reactions and precipitation of cations. The second container was a one-liter plastic container for anion determination. These containers were tightly corked and preserved in an ice-cooled container to keep the temperature below $20{ }^{\circ} \mathrm{C}$ and were eventually transferred to the laboratory for analysis within three days. After samples for laboratory analysis were taken, water sample were also taken out of the well for on-the-spot determination of some physical parameter such as color, odor, taste, temperature, $\mathrm{pH}$, conductivity and turbidity. Temperature, $\mathrm{pH}$, conductivity and resistivity were measured using (WAGTECH) meters. The depth to water level was also measured using a tape and recorded. On return from field, the samples were transferred from the coolers and kept.

\section{Results}

\subsection{Trace Elements}

Trace elements are generally present in small concentration in natural water system. Their occurrence in groundwater and surface water is due to natural sources such as dissolution of naturally occurring minerals containing trace elements in the soil zone or the aquifer material or to human activities such as mining, fuel spill, smelting of ores, agricultural activity improper disposal of industrial wastes. Trace metals like iron $(\mathrm{Fe})$, copper $(\mathrm{Cu})$, zinc $(\mathrm{Zn})$ are very important for the proper functioning of the biological system and their deficiency or excess in the human system can lead to a number of disorders. Other trace metals like lead $(\mathrm{Pb})$ are not only biologically non-essential but toxic at low concentrations.

\subsubsection{Iron}

Iron values in surface water in Katsina ranged between $0.42 \mathrm{mg} / \mathrm{L}$ to $2.85 \mathrm{mg} / \mathrm{L}$ with mean and median values of $1.16 \mathrm{mg} / \mathrm{L}$ and $0.69 \mathrm{mg} / \mathrm{L}$ respectively. The groundwater had concentration range between $0 \mathrm{mg} / \mathrm{L}$ to $0.045 \mathrm{mg} / \mathrm{L}$ with mean and median of $0.08 \mathrm{mg} / \mathrm{L}$ and $0.023 \mathrm{mg} / \mathrm{L}$ respectively (Table 1 ). All samples from surface water are above the $0.2 \mathrm{mg} / \mathrm{L}$ of WHO (World Health Organization) (2011) and 0.3 $\mathrm{mg} / \mathrm{L}$ of NSDWQ (Nigerian Standard for Drinking Water Quality, [10]). This may result from the chemical weathering of rock or lateralization. The groundwater conforms to WHO (2011) and NSDWQ [10] recommended limit of $0.2 \mathrm{mg} / \mathrm{L}$ and $0.3 \mathrm{mg} / \mathrm{L}$ respectively.

\subsubsection{Lead}

All the surface water samples analyzed have values ranging between $0.01 \mathrm{mg} / \mathrm{L}-0.46 \mathrm{mg} / \mathrm{L}$, with mean and median concentrations as $0.026 \mathrm{mg} / \mathrm{L}$ and $0.024 \mathrm{mg} / \mathrm{L}$. The groundwater had values between $0 \mathrm{mg} / \mathrm{L}$ to $0.016 \mathrm{mg} / \mathrm{L}$. The mean and median values for lead concentration in groundwater are $0.007 \mathrm{mg} / \mathrm{L}$ and 
Table 1 Descriptive statistics of trace elements concentration in surface and groundwater samples of Katsina city.

\begin{tabular}{|c|c|c|c|c|c|c|c|c|c|c|}
\hline \multirow{2}{*}{ Parameters } & \multicolumn{4}{|c|}{ Surface water } & \multicolumn{4}{|c|}{ Groundwater } & \multicolumn{2}{|c|}{ Limits } \\
\hline & Minimum & Maximum & Mean & Median & Minimum & Maximum & Mean & Median & WHO & NSDWQ \\
\hline $\mathrm{Fe}^{2+}$ & 0.4165 & 2.8498 & 1.1607 & 0.69 & 0 & 0.0448 & 0.0811 & 0.023 & 0.2 & 0.3 \\
\hline $\mathrm{Zn}^{2+}$ & - & - & 0 & 0 & - & - & 0 & 0 & 5 & 0.3 \\
\hline $\mathrm{Cr}^{+}$ & - & - & 0 & 0 & - & 0 & 0 & 0 & 0.05 & 0.05 \\
\hline $\mathrm{Cu}^{2+}$ & 0 & 0.0219 & 0.009 & 0.003 & 0 & 0.006 & 0.003 & 0.003 & & \\
\hline $\mathrm{Ni}^{2+}$ & - & - & 0 & 0 & - & - & 0 & 0 & 0.02 & 0.02 \\
\hline $\mathrm{Cd}^{2+}$ & - & - & 0 & 0 & - & - & 0 & 0 & 0.003 & \\
\hline $\mathrm{Pb}^{2+}$ & 0.01 & 0.0461 & 0.026 & 0.024 & 0 & 0.016 & 0.007 & 0.01 & 0.01 & 0.01 \\
\hline $\mathrm{Mn}^{2+}$ & - & - & - & 0 & - & - & - & 0 & 0.5 & 0.2 \\
\hline
\end{tabular}

$0.007 \mathrm{mg} / \mathrm{L}$ respectively (Table 1$)$. The WHO (2011) and NSDWQ [10] limit is $0.01 \mathrm{mg} / \mathrm{L}$. This implies that all the surface water analyzed in Kura is polluted by lead. This high concentration of lead in surface water may be as a result of the surface water running through a weathered lead bearing rock.

\subsubsection{Copper}

Copper in the analyzed surface water samples ranged between $0 \mathrm{mg} / \mathrm{L}$ to $0.022 \mathrm{mg} / \mathrm{L}$, the mean and median values are $0.009 \mathrm{mg} / \mathrm{L}$ and $0.003 \mathrm{mg} / \mathrm{L}$ respectively. The range of values of copper in groundwater is between $0 \mathrm{mg} / \mathrm{L}$ to $0.006 \mathrm{mg} / \mathrm{L}$, the mean and median values are $0.003 \mathrm{mg} / \mathrm{L}$ and 0.003 $\mathrm{mg} / \mathrm{L}$ respectively (Table 1 ). All the water samples analyzed in Kura conform to WHO (2011) safe limit of $2 \mathrm{mg} / \mathrm{L}$ for copper, above which can cause gastrointestinal disorder. Cadmium, Arsenic, Manganese, Nickel, Chromium and Zinc were below detection limit of AAS in all the analyzed samples.

\subsection{Major Anions}

The major anions analyzed based on their use in water classification are bicarbonate ion $\left(\mathrm{HCO}_{3}{ }^{-}\right)$ carbonate ion $\left(\mathrm{CO}_{3}{ }^{2-}\right)$, sulphate ion $\left(\mathrm{SO}_{4}{ }^{2-}\right)$ and chloride ion $\left(\mathrm{Cl}^{-}\right)$.

4.2.1 Bicarbonate Ion $\left(\mathrm{HCO}_{3}{ }^{-}\right) /$Carbonate Ion $\left(\mathrm{CO}_{3}{ }^{2-}\right)$

Bicarbonate $\left(\mathrm{HCO}_{3}{ }^{-}\right)$in the analyzed surface water samples have values that ranged between $65 \mathrm{mg} / \mathrm{L}-98$ $\mathrm{mg} / \mathrm{L}$ with mean and median values of $77 \mathrm{mg} / \mathrm{L}$ and $78.5 \mathrm{mg} / \mathrm{L}$ respectively. The groundwater had range of values between $5 \mathrm{mg} / \mathrm{L}$ to $356 \mathrm{mg} / \mathrm{L}$. The mean and median for groundwater are $159.8 \mathrm{mg} / \mathrm{L}$ and $122 \mathrm{mg} / \mathrm{L}$ respectively. Carbonate $\left(\mathrm{CO}_{3}{ }^{2-}\right)$ was not detected in all the analyzed samples (Table 2). The bicarbonate concentration in water of Kura is in conformity with the WHO and NSDWQ limits for bicarbonate of 1,000 $\mathrm{mg} / \mathrm{L}$. The distribution bicarbonate is shown in Table 2.

\subsubsection{Chloride $\left(\mathrm{Cl}^{-}\right)$}

The chloride content of groundwater may be due to the presence of soluble chlorides from rocks, which contain clay minerals, connate water, intruded sea water or domestic sewage. Chloride concentrations in the surface water of the study area ranged between $11.70 \mathrm{mg} / \mathrm{L}$ to $16.80 \mathrm{mg} / \mathrm{L}$ with mean and median values of $14.6 \mathrm{mg} / \mathrm{L}$ and $14 \mathrm{mg} / \mathrm{L}$ respectively (Table 2). The groundwater had range between $9.9 \mathrm{mg} / \mathrm{L}$ to $79.2 \mathrm{mg} / \mathrm{L}$ with mean and median values of 27.06 $\mathrm{mg} / \mathrm{L}$ and $15.22 \mathrm{mg} / \mathrm{L}$ respectively. It is the second most abundant of the principal anions. The concentrations of chloride in both surface and groundwater of the study area conform to the WHO and NSDWQ safe limit of $240 \mathrm{mg} / \mathrm{L}$ and $250 \mathrm{mg} / \mathrm{L}$ respectively. The distribution of chloride in Kura is shown in Table 2.

\subsubsection{Sulphate $\left(\mathrm{SO}_{4}{ }^{2-}\right)$}

Sulphate values analyzed in the surface water ranged between $7.1 \mathrm{mg} / \mathrm{L}$ to $8 \mathrm{mg} / \mathrm{L}$, the mean and median values are $7.69 \mathrm{mg} / \mathrm{L}$ and $8 \mathrm{mg} / \mathrm{L}$ respectively. The groundwater had range between $7 \mathrm{mg} / \mathrm{L}$ to $48 \mathrm{mg} / \mathrm{L}$ with mean and median values of $11.23 \mathrm{mg} / \mathrm{L}$ and $7 \mathrm{mg} / \mathrm{L}$ respectively (Table 2 ). The values recorded for 
Table 2 Descriptive statistics of results of major anions in the samples.

\begin{tabular}{|c|c|c|c|c|c|c|c|c|c|c|}
\hline \multirow[b]{2}{*}{ Parameters } & \multicolumn{4}{|c|}{ Surface water } & \multicolumn{4}{|c|}{ Groundwater } & \multicolumn{2}{|c|}{ Limits } \\
\hline & Minimum & Maximum & Mean & Median & Minimum & Maximum & Mean & Median & $\begin{array}{l}\text { WHO } \\
2011\end{array}$ & $\begin{array}{l}\text { NSDWQ } \\
2007\end{array}$ \\
\hline Temperature $\left({ }^{\circ} \mathrm{C}\right)$ & 25.0 & 28.0 & 28.92 & 26.40 & 24.5 & 28.6 & 26.66 & 26.5 & variable & Ambient \\
\hline $\mathrm{Ph}$ & 5.28 & 6.53 & 6.92 & 5.47 & 5.39 & 6.50 & 6.03 & 6.16 & $7-8.5$ & $6.5-8.5$ \\
\hline $\mathrm{EC}$ & 99 & 139.5 & 111.6 & 118.80 & 128 & 1011 & 358 & 321 & 1,000 & 1,000 \\
\hline $\mathrm{TDS}(\mathrm{mg} / \mathrm{L})$ & 54.2 & 86.38 & 72.90 & 70.09 & 45.2 & 558.2 & 228.8 & 200.31 & 1,000 & 500 \\
\hline Sulphate (mg/L) & 7.1 & 8 & 7.69 & 8 & 7 & 48 & 11.23 & 7 & 100 & 100 \\
\hline Chloride (mg/L) & 11.70 & 16.80 & 14.6 & 14 & 9.9 & 79.2 & 27.06 & 15.22 & 250 & 240 \\
\hline Bicarbonate(mg/L) & 65 & 98 & 77 & 78.5 & 5 & 356 & 159.8 & 122 & 1,000 & 1,000 \\
\hline Nitrate (mg/L) & 0.1 & 0.4 & 0.443 & 0.59 & 0.3 & 13.8 & 2.78 & 0.9 & 50 & 50 \\
\hline
\end{tabular}

sulphate were lower than both WHO and NSDWQ limits of $250 \mathrm{mg} / \mathrm{L}$.

\subsubsection{Nitrate $\left(\mathrm{NO}_{3}{ }^{-}\right)$}

The range of values for nitrate in surface water in the study area is between $0.1 \mathrm{mg} / \mathrm{L}$ to $0.4 \mathrm{mg} / \mathrm{L}$ with mean and median of $0.443 \mathrm{mg} / \mathrm{L}$ and $0.59 \mathrm{mg} / \mathrm{L}$ respectively (Table 2). The range for groundwater is between 0.3 $\mathrm{mg} / \mathrm{L}$ to $13.8 \mathrm{mg} / \mathrm{L}$ with mean and median values of $2.78 \mathrm{mg} / \mathrm{L}$ and $0.9 \mathrm{mg} / \mathrm{L}$ respectively. The samples from both surface and groundwater in the study area conform to the WHO and NSDWQ recommended value of $50 \mathrm{mg} / \mathrm{L}$. Groundwater showed the highest concentration of nitrate, but this may be as a result of its nearness to a grave yard which is just about $200 \mathrm{~m}$ away and in downs lope direction. Table 2 showed the distribution of nitrate concentrations in the study area [3].

\section{Discussion}

\subsection{Environmental Impact of Irrigation in Katsina City}

As discussed earlier that most parts of the study area engaged in small scale commercial irrigation through water transfer from Tilla streams. This activity has created a full-time dry season profitable employment for farmers in this area. The people living in the area have the advantage to be employed all year round because the land is also farmed during the wet season. The streams provide water for domestic uses to the people of the area around Kofar Marusa which is consumed locally. These created jobs help to eliminate the rural urban migration in the study area.

Secondly, the Ginzo and Tilla streams also improved the condition of living to the people in the study area in term of irrigation water supply. For example, in Katsina city today local irrigators send their children to private schools, which may cause them N5,000-N10,000 termly which was unaffordable prior to the irrigation scheme. Garden cultivators and their family members now can go to private clinics for better medical attention. Apart from jobs creation, the irrigated farming and in fish farming also result in creation of more jobs and services, including white collar jobs due to the creation of private clinics, schools, food processing local industry e.g. tomatoes processing industry. The government of Katsina State has also shown interest in setting a tomato industry in the State.

Negative impact of the scheme is flooding and salinity. Most of the fertile land at the flood plains of the streams have been reduced or completely destroyed in some parts of Kofar Durbi and Kofar Marusa. Also between months of August-September, 2013, a lot of farms were washed away. This flooding also led to some health complications, such as the outbreak of water-borne diseases like cholera which affected some households, mostly women and children. Many people were also forced to flee their homes due erosion hazards.

Salinity buildup in groundwater is a major environmental impact of large scale irrigation and urban Agriculture within the city (Fig. 2). This is due to 


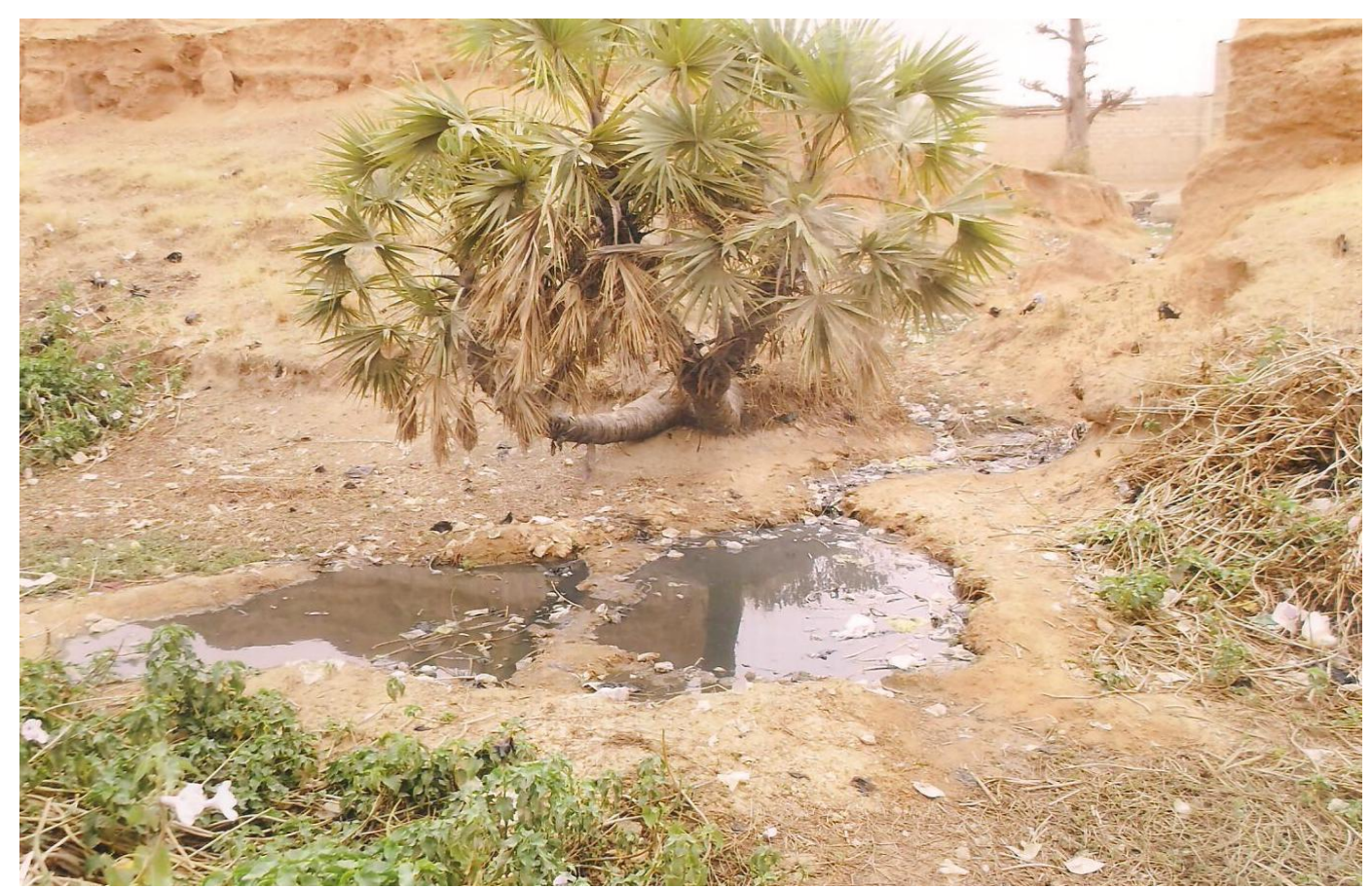

Fig. 2 A puddle behind Katsina City wall at Yammawa Slum area.

poor soil and water management practice. Good soil and water management practice with the provision of adequate surface and sub-surface drainage would help to stop or slow down the process. However, maintenance to repair and reshaped the unlined channels and the drainage system is ongoing in the area. This is essential in improving the water management in the area.

\section{Recommendations}

The dependent of people on surface and well waters is due to lack of potable pipe-borne water. In view of this; the government should embark on the provision of potable water for the people of Katsina city and its environ. If pipe-borne water is supplied to all nooks and crannies of the area, less emphasis would be placed on surface and well water which in most cases are shallow and close to gardens, farms, sewage from latrines and soak-aways. Reports by some inhabitants of the area of regular stomach pains may be associated with the concentration of lead above recommended drinking water in surface water of this area. Laws should be made to prevent people from encroaching into the irrigated farms for settlement.

\section{References}

[1] Nur, A., Ishaku, J. M., and Taiyib, A. 2012. "Spatial Distribution of Chemical Facies Using Geographical Information System (GIS) in Michika, Northeastern Nigeria." Research Journal in Engineering and Applied Sciences 1 (2): 102-9.

[2] United Nations. 2006. "World Water Development Report 2." United Nation Scientific and Cultural Organization (UNESCO). UNESCO Publishing.

[3] Lee, G. F., and Jones-Lee, A. 2007. "Focus on Irrigated Agriculture Pollution of Groundwater, Excerpt from Groundwater Quality Protection Issue.” Report of Lee, G. F., \& Associates, Macero, E. I., CA, February 2007; presented in part at $\mathrm{Ca} / \mathrm{NV}$ AWWA Fall Conference, Sacramento, CA, October, 2007.

[4] Edmunds, W. M., Darling, W. G., and Kinniburg, D. G. 1998. "Solute Profile Technique for Recharge Estimation in Semi-arid Region in Estimation of Natural Groundwater Recharge." Reidel Deidrecht, edited by Simmers, I., 139-57.

[5] Lawal, M. B. 2012. "Effect of Agricultural Pollutants on the Quality of Groundwater in Kura Area, Kano State, Nigeria." An Unpublished M. Tech thesis, Dept. of Geology, Federal University of Technology, Minna.

[6] Ladan, S. I. 2014. "Assessment of Sewage Disposal Methods and Environmental Health Impacts in Katsina 
Metropolis, Northern Nigeria." Journal of Life Sciences and Technologies 2 (1): 38-43.

[7] Ogezi, A. E. 1998. "Origin and Evolution of the Basement Complex on Northwestern Nigeria in the Light of New Geochemical and Geochronological Data." In Precambrian Geology of Nigeria, edited by Oluyide, P. O., Mbonu, W. C., Ogezi, A. E., Egbuniwe, I. G., Ajibade, A. C., and Umeji, A. C. Precambrian Geology of Nigeria Geological Survey of Nigeria Publication, 301-12. Kaduna, Eshoo Printers.

[8] Kankara, I. 2014. "The Geochemical Characterization of Rocks in Funtua Sheet 78 Northeast, North Western Nigeria." An Unpublished Ph.D. thesis, Department of
Geology, Federal University of Technology Minna, Nigeria.

[9] Mary, B., and Thomas, H. 2001. "Non-point Source of Pollution in Irrigated Agriculture." Geological Survey of Nigeria Publication, 8055.

[10] Nigerian Standard for Drinking Water Quality. 2007. "Standard Organization of Nigeria. Nigerian Standard for Drinking Water Quality Publication." Retrieved from http//www.unicef.org/Nigeria/ng_publicationNigeria_Sta ndard_for_Drinking_Water_Quality.pdf.

[11] DR 2800 Spectrophotometer Procedure Manual. 2007. 2nd Edition. Retrieved from www.hach.com/asset-get.download. 